\title{
Exploration of Engineering Case Teaching and Training of Application Undergraduates
}

\author{
Changsen Zhang ${ }^{1, a}$, Qisheng $\mathrm{Wu}^{1, \mathrm{~b}}$, Jinghua Chen ${ }^{1, \mathrm{c}}$ \\ ${ }^{1}$ College of Materials Engineering Yancheng Institute of Technology, Yancheng 224051, China

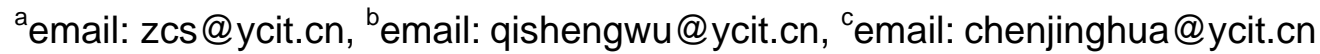

Keywords: engineering case; case method; application undergraduates training

\begin{abstract}
The Paper introduces the development of case method and existing problems of the traditional teaching methods on the training of application undergraduates. On application undergraduates, combining practice of case method of engineering, the advantages of engineering case method is discussed. The engineering case method is an effective teaching method on application undergraduates, effectively help students in active learning and initiative and improve the students' practice and innovation ability, and teamwork spirit.
\end{abstract}

\section{Introduction}

Since the 1990s, the higher engineering education of US firstly focused on traditional engineering education about emphasizing specialization and science to separate the "great engineering view" educational idea which is came up with the project phenomenon itself and issued the call of "return to project" [1]. On the other hand, with the popularity of our country's higher education, the quality of higher school students also has great changes. The original elite education model is not suitable for a popular style[2]. In this context, the most of engineering colleges and universities carry out the teaching reform and strengthen the engineering education to adapt to the popular education. The core content of university is to train applied talent to adapt to personnel market and local economic construction requirements. More and more colleges and universities take lots of measures to foster engineering graduates' abilities of dealing with engineering problems such as open comprehensive and design experiment courses, advocate "real topic really do" for graduation project (dissertation)[3] and develop the "college students" innovation plan' and other extracurricular science and technology practice activities and competition activities, etc. At the same time, bringing the engineering case teaching method in the specialized engineering teaching that can enrich the content of student training and widening the scope of implementation which makes more students to join the engineering practice and make up the insufficiency for other teaching methods. The combination of theory and practice teaching model can shorten the distance between the theoretical teaching and production practice to meet the industrial enterprise requirement by engineering education which reflects teaching ideas and training target of "facing the engineering" [4].

In this paper, according to the requirements of engineering applied talents, there will be an exploration and discussion of engineering case teaching method in engineering application talents.

\section{The Development of Case Teaching}

Case teaching can be traced back to the time of ancient Greece from philosopher Socrates method, but it really regarded as a teaching method of the formation and application was in 1910, in law school and medical school of Harvard University. At that time, Harvard medical school had a reform for traditional medical teaching that is taking medical cases of clinic doctors' record for teaching, and then students discussed and researched according to these cases, which namely case teaching mode. Law school mainly takes the court case for the teaching content, in the classroom students fully participate in discussion and the assumption of the case considered as the examination questions. There is no accordance between its teaching method and traditional teaching which leads 
to the slow development.

In 1920, for the development of enterprise, the US Rockefeller consortium was badly in need of cultivating enterprise talents. Therefore, it provided funding for Harvard business school to have new teaching method test. In consideration of successful case teaching of medical school and law school, business school took case teaching as a test of new teaching method and achieved a good effect. Wallace, dean of Harvard business school published the first cases portfolio in 1921. Since then, case teaching has been widely used in the study of business management. Since the 1950s, Canada, Britain, France, Germany, Italy, Japan and Southeast Asian countries introduced case teaching method in management education.

In China, with the reform and opening to the outside world, case teaching was introduced and gradually developed. In 1980, China's State Science and Technology Commission, State Economic Commission and Ministry of Education had the cooperation with the U.S. government. Set up the Senior Management Cadres Training Centre in Dalian which was composed of teachers group from six American universities to teach and train Chinese enterprise management personnel. Dalian training center imported management theory and management method from the U.S., actively popularized the applied case teaching method which was welcomed by the students and the teaching effect was remarkable. From now on, case teaching was gradually accepted and applied by our education circle. In 1983, the case questions were appeared in the national management cadre test which was organized by the state economic commission of the organization. During "the 8th Five-Year-Plan” period, the case teaching research and application have been strengthened and development and a large number of case assemblies were issued or published in the domestic area. Our country's case teaching started late in both theory and practice aspects, but the case teaching has being accepted by more and more people, and widely applied and comprehensive developed. So far, many universities adopt case teaching not only widely in management specialty teaching content and teaching method, but also are gradually taken in other professional majors [4-8].

\section{Insufficient of traditional engineering profession teaching methods in the talents application}

From the view of engineering application talents, there are some following disadvantages of traditional engineering profession. The engineering educated talents are disjoined from out engineering practice and they cannot meet the front line requirements of industry and project.

(1) There are some differences between the exiting theoretical teaching system and the practice teaching system and the requirements of the applied talents education project. Students are obviously lacking of engineering practice and training during the period of school. The students' actual work skills cannot achieve the basic requirements of industrial and engineering for the senior application talents.

(2) The theory and practice cannot be connected and the ability to solve practical problems is weak. Universities cannot provide practical teaching environment or sufficient investment which lead to development of practical teaching (such as experiment courses, professional experiment courses, etc) cannot meet the engineering college students' training requirements.

(3) Practice link is restricted and the site of internship cannot be satisfied. Even there are still some contacts between universities and enterprises in our country, along with our country's enterprise restructured and merged, many enterprises for own economic benefit and security and other reasons, they do not accept the students' internship. Though they agree to allow students to practice but only mainly by visiting form like making two-week cognition practice or four-week graduation practice. The enterprise plays an unimportant role in training students' project.

(4)Teacher is the main body of traditional teaching engineering courses while the student is passively accepted which is focused to learn and lack of encourage and discussion. And after the expansion of enrollment since 1999, universities have to introduce more teachers and lots of them are young teachers without enough front line practice and they are short of special engineering practice. Therefore, during the lecture, they cannot connect the practice with theory properly.

(5) Traditional engineering courses offer the general principles and methods for understanding objects and solving problems in professional field. The main core in classroom is passing on 
knowledge and students' priority is learning knowledge. For industrial enterprise, they do not pay more attention on practical problems and there is no pertinence for enterprise production problems or engineering problems which causes students can not have enough abilities to use the knowledge analysis for solving practical problems.

\section{The practice of engineering case teaching in specialized course teaching}

In order to adapt to the demand of broad caliber material or application talents, we decreased the class hour for specialized course. Everyone is worried about whether it may affect the quality of teaching if the class hour is not enough. And they are afraid of students can not adapt to the enterprise environment without learning so much knowledge. Under this condition, as a result of learning and discussion, firstly recognizing the status and the function of professional class in undergraduate teaching and regard as the universities can not pass on all the knowledge to students during the studying period. The main task of the specialized course is not only transfer knowledge to students but also make students to know well the scientific thinking method of this studying field, and then students can practice ability for project to meet the need of cultivating talents.

The way of cultivate students' engineering ability. We combine the existing experiment and practice and the current situation, then have a try on professional engineering case method. According to the different knowledge of powder engineering and concrete science and engineering and materials technology and thermal engineering, through teachers who have practice experience and the related enterprise engineers collect related enterprise production and actual cases to write representative and suited cases for teaching. The cases take the some key examples which are more related to production (or engineering) and professional theory. To combine the project cases and professional knowledge closely which are used in professional teaching.

During the powder engineering teaching, usually involving grinding, classification, the homogenization, storage, transportation and other unit operation processes. At beginning of each unit operation, enumerating engineering application example in this unit and putting forward the problems of science and engineering and the basic methods to solve these problems. At the same time, making students to be clear about the industry background and purpose of this unit and they should pay attention to the problems and how to solve problems. For example, combine the powder engineering of grinding and classification equipment to list the quality and output and technological process of sample which is domestic cement enterprise $\phi 4.2 \times 13 \mathrm{~m}$ cement grinding machine. To let students to analysis and discuss the effects of different process and different classification equipment for output thus think out the project for increasing quality of grinding machine.

In the concrete science and engineering course, show analysis of problems and solutions for Sutong Bridge and Qinghai-Tibet Railway to students. Such as combining the mass concrete content and taking the Yangtze River three gorges water conservancy hub project for typical cases. Encouraging students to discuss the concrete construction problems and learn to how to take measures in different seasons. Then integrating the wind and power set assemble project and equipment of $29.2 \mathrm{~m} \times 9.3 \mathrm{~m} \times 3 \mathrm{~m}$ concrete in $5 \mathrm{MW}$ engine, amount of concrete is about $315 \mathrm{~m} 3$, in Yancheng industry base of Huarui Wind Power LTD. Taking this as the case for construction scheme which guides the student to use flexible knowledge.

Through the engineering case teaching, to stimulate the students' subjective initiative and interest in learning which makes students strongly seeking knowledge and thinking is very active. So the teaching efficiency and effect is high.

\section{The advantage of engineering case teaching in engineering teaching}

The engineering case teaching makes theory and practice with better combination which is benefit for improving students' abilities of analysis and solving problems and engineering practice. As the saying goes: "Teaching a person to fishing which is better than just giving fishes directly". Project cases are from production or engineering practices those are real events with strong practicality. Through the project cases, the abstract professional theory would be more specific. 
Under teachers' guidance, students use their knowledge and specific engineering case analysis to experience the problems in practical production or project. For achieving combination of theory and practice, students get knowledge and experiences at the same time which solve the problem of students only understand knowledge but can not use them for practical things. This effectively fosters students' the ability of applying comprehensive knowledge and working independently with innovation spirit.

Engineering case teaching is advantageous to improve the students' enthusiasm and initiative. In the engineering case teaching, it needs that students analyze and discuss the specific engineering case by themselves. Meanwhile, asking questions and answering between each other and finding the relevant knowledge in case background materials. This kind of teaching method changes the way of accepting knowledge positively and exploring engineering case teaching. Students apply their basic theoretical knowledge and analysis methods to practice thinking, analyzing and studying that embody the position of students in study. Then improve the students' enthusiasm and initiative effectively.

Engineering case teaching is beneficial to strengthen students' teamwork spirit. This case teaching encourages students to think dialectically. From different perspective, to discuss the same problem and advocating exchange, discussion, inspiration and criticism. Helping students to organize knowledge and answer difficult points. Through the discussion and brainstorm, finally several classmates finish the project together. This process can cultivate students to put forward questions and express personal point of view and the ability of the case analysis ability with team cooperation spirit.

Teachers and students may have more interaction through engineering case teaching. In traditional teaching, teacher is a sender while student is a negative receiver. Teachers provide theory knowledge, students receive it without thinking by themselves. However, in case teaching, the relationship of teachers and students is "Teachers and students, teaching and learning, are complementary for each other". In this teaching method, students positively take part in and they are the main part of reading and case analysis and classroom discussion. In case teaching, teachers always play the role of "director". Teachers not only should choose good "scripts" but also need to improve the occasion in different situations to make each student "act" adequately to get the most profit. Case teaching strengthens the communication between teachers and students and actives classroom atmosphere which is difficult compared to the traditional teaching mode.

Engineering case teaching is helpful to improve the teachers' quality and teaching level. From teachers' side, they need higher teaching knowledge structure, better teaching ability and work attitude and teaching responsibility than traditional ways. It requires teachers to have both broad and profound theoretical knowledge and rich practical experience which needs teachers constantly update teaching contents and supplement the lesson plans and requests the teacher to pay more attention to the present production status and engineering practice. Constantly finding suitable cases from enterprise and engineering practice so teaching activities could be kept in a active enterprising state and constantly improve teaching quality and teaching level.

Engineering case teaching and other teaching can be complementary and promote together. In engineering course teaching practice, there is more than one perfect teaching method and different methods can not be replaced by each other. Case teaching method and other teaching means such as lectures, design, practices, experiment should be complementary and be promoted by each other to make more benefit at cultivating engineering applied talents.

To sum up, the advantages of engineering case teaching is introducing actual project cases to classroom and through teacher's guide to correctly build a analysis and discussion atmosphere which makes student feel the essence of production practice and engineering design. During the discussion and analysis, they can deeply understand the function as a engineer for product research and production development in the future. At the same time, they still can know that how to use the theory knowledge to solve practical problems and design scheme and how to work in a team with unity cooperation. 


\section{Conclusion}

The core of engineering case teaching is cultivating the students' ability as the new teaching method. It is different from traditional teaching method, teachers is in a single subject status with one-way communication in traditional teaching method. And teaching materials are kept for many years without changing. This engineering case teaching is a revolution for traditional ones. Engineering case teaching embodies people-oriented teaching theory and modern psychology constructivism theory which adapts to learners' knowledge construction and the order for accepting inner knowing. It is consistent with the socialization process and the objective law. On the one hand, engineering case teaching requires teachers and students to have more requests and provides broader space for comprehensive analysis. On the others hand, it is important for fostering students' ability of analyzing and solving problems. After all, engineering case teaching is a kind effective method for educating engineering application talents.

\section{Conclusion}

Based on the analysis of the mechanical theory as the foundation, designed the soccer robot pick the ball institutions optimal design process, found aim function, select design variables and the corresponding optimization algorithm to optimize a complete set of institutions. At last through the test to get the final performance parameters of the institution. Experiments show that the system has higher accuracy and stability, the new optimize pick the ball have design basic requirements, and achieved good ideal control effect.

\section{Acknowledgement}

In this paper, the research was supported by “Twelfth Five-year” Key Professional of College of Jiangsu Province (Project No.2012-182) and Education Educational Reform Research of Yancheng Institute of Technology (2013).

\section{References}

[1]Z. H. Wang and Z.G. Chen. The concept of engineering education and the characteristics of engineering undergraduate colleges. China higher education research, June, 2006, pp.29-31. [2]C. S. Zhang. The exploration of undergraduate application inorganic non-metal teaching reform. The Border Economy and Culture, April, 2007,PP.122-125.

[3]C. S. Zhang, Q. S.Wu, G. H. Hou. The construction of applied graduates design team training mode. Journal of Technology College Education, vol. 28, 2009, pp. 118-121.

[4]D. Xu. The professional culture of case teaching and engineering management. Journal of Jiangxi University of Finance and Economics, March,2006, pp. 117-121.

[5]C. G. Sun and M. G. Ge. Case teaching and the development of teachers'professional capabilities. China Adult Education, September, 2004, pp. 89-90.

[6]Z. J. Wan and J.M, Huang. Ten measures of improving students' project ability for building materials engineering direction. Journal of Architectural Education in Institutions of Higher Learning, vol.19, 2010,pp. 7-10.

[7]B. J. Yan. Case teaching applied in teaching material mechanics. Tech Information Development and Economy, vol.2007,pp.257.

[8]X. H.Huang and J. P. Zhuang. The case method applied in building materials course teaching. Fujian Building Materials. May 2008, pp. 127-129. 